Note

\title{
Novel Hydroquinone as a Matrix Metallo-proteinase Inhibitor from the Mushroom, Piptoporus betulinus
}

\author{
Hirokazu Kawagishi, ${ }^{1, \dagger}{ }^{\dagger}$ Keiko Hamajima, ${ }^{1}$ and Yoshimasa Inoue ${ }^{2}$ \\ ${ }^{1}$ Department of Applied Biological Chemistry, Faculty of Agriculture, Shizuoka University, 836 Ohya, \\ Shizuoka 422-8529, Japan \\ ${ }^{2}$ Target Discovery Group 2, $R \&$ D Laboratories, Nippon Organon K. K., 5-90 Tomobuchi-cho 1-chome, \\ Miyakojima-ku, Osaka 534-0016, Japan
}

Received July 4, 2002; Accepted August 7, 2002

The novel hydroquinone, $(E)-2-(4-h y d r o x y-3-$ methyl-2-butenyl)-hydroquinone, and known compound, polyporenic acid $C$, were isolated as matrix metallo-proteinase inhibitors from the mushroom, Piptoporus betulinus.

Key words: matrix metallo-proteinase; inhibitor; mushroom; Piptoporus betulinus

Extracellular matrix (ECM) remodeling is essential to maintain tissue homeostasis in every organ of the body. Physiological ECM remodeling has been proposed to be mediated by members of the matrix metalloproteinases (MMPs). ${ }^{1)}$ Important members of these enzymes are collagenase (MMP-1), which cleaves all three alpha-chains of native interstitial collagens; $72 \mathrm{kDa}$ gelatinase (MMP-2) and $92 \mathrm{kDa}$ gelatinase (MMP-9), which cleave gelatin and the basement membrane; and stromelysin (MMP-3), which degrades a wider variety of protein substrates including gelatin, fibronectin, and laminin, as well as the core protein of cartilage proteoglycans. In addition, MMPs have been implicated in several pathological processes including arthritis, tumor growth, metastasis, periodontal disease, and multiple sclerosis. $^{2-6)}$ Therefore, the discovery of potent inhibitors of these enzymes is a highly attractive endeavor both scientifically and commercially.

In the course of screening for the inhibitory activity of mushroom extracts, we found that an extract of the mushroom, Piptoporus betulinus, inhibited MMPs. We describe here the isolation, structure and biological activity of the new inhibitor from this mushroom.

General experimental procedure. NMR spectra were measured by a Jeol Lambda-500 spectrometer and are given in $\mathrm{ppm}(\delta)$ downfield from internal TMS. Mass spectra were recorded by a Jeol DX-302 mass spectrometer, and a Jasco grating infrared spectrophotometer was used to record the IR spectra.
Fungus material. Mature fruiting bodies of Piptoporus betulinus (Bull.: Fr.) Karst. were collected from Kamikuisshiki village in Yamanashi Prefecture of Japan.

Extraction and isolation. Fresh fruiting bodies of $P$. betulinus $(5.8 \mathrm{~kg})$ were extracted with $\mathrm{EtOH}(101$, 5 times), and the solution was concentrated under reduced pressure and partitioned between $\mathrm{CHCl}_{3}$ and $\mathrm{H}_{2} \mathrm{O}$, and then between EtOAc and $\mathrm{H}_{2} \mathrm{O}$. The residue $(96.7 \mathrm{~g})$ obtained after removing EtOAc was fractionated by silica gel flash $\mathrm{CC}\left(90 \%, 60 \% \mathrm{CHCl}_{3}\right.$ /acetone; $\left.70 \%, 50 \% \mathrm{CHCl}_{3} / \mathrm{MeOH} ;, \mathrm{MeOH}\right)$ to obtain 14 fractions. Fraction $10(9.58 \mathrm{~g})$ was further separated by reverse-phase HPLC $\left(70 \% \mathrm{MeOH} / \mathrm{H}_{2} \mathrm{O}\right)$, giving 1 (3.0 mg). Compound $2(3.0 \mathrm{mg})$ was obtained from fraction $8(115 \mathrm{mg})$ by reverse-phase HPLC (90\% MeOH $\left./ \mathrm{H}_{2} \mathrm{O}\right)$.

MMP assay. DNA fragments coding the catalytic domain of human MMP-1 and human MMP-9 and a DNA fragment coding from the pro-domain to catalytic domain of human MMP-3 were amplified by a polymerase chain reaction from cDNA of HT1080 cells that had been stimulated with $0.01 \mathrm{~mm}$ of phorbol 12-myristate 13-acetate (Sigma, St. Louis, MO, U.S.A.). The $5^{\prime}$-end of each PCR primer was added to a sequence for the appropriate restriction enzyme site. The amplified DNA fragments were cloned into a cloning vector and then introduced into a commercially available expression vector containing His-6 tag sequence at the end of $N$-terminus. Recombinant proteins were expressed in Escherichia coli cells and purified by Ni-NTA resin (Qiagen, Valencia, CA, U.S.A.) and refolded. Recombinant MMP-3 was activated by incubating with $1 \mathrm{~mm} p$-aminophenylmercuric acetate (Sigma, St. Louis, MO, U.S.A.) for $1 \mathrm{~h}$ at $37^{\circ} \mathrm{C}$. Each test compound was dissolved in DMSO and diluted with a reaction buffer $(50 \mathrm{mM}$ Tris, $150 \mathrm{~mm} \mathrm{NaCl}, 10 \mathrm{~mm} \mathrm{CaCl}_{2}$, and 0.05\% Brij-35 at $\mathrm{pH}$ 7.5). Twenty-five $\mu \mathrm{l}$ of the compound solution was mixed with $25 \mu \mathrm{l}$ of the diluted enzyme solution

$\dagger$ To whom correspondence should be addressed. Fax: +81-54-238-4885; E-mail: achkawa@agr.shizuoka.ac.jp 
Table 1. ${ }^{1} \mathrm{H}$ - and ${ }^{13} \mathrm{C}-\mathrm{NMR}$ Data for Compound 1 (in $\left.\mathrm{CDCl}_{3}\right)^{\mathrm{a})}$

\begin{tabular}{ccc}
\hline \hline Position & ${ }^{1} \mathrm{H}$ & \\
& $\delta$ (multiplicity, $J$ in $\mathrm{Hz})$ & ${ }^{13} \mathrm{C}$ \\
\hline 1 & - & 148.9 \\
2 & - & 129.7 \\
3 & $6.53(\mathrm{~d}, 3.2)$ & 117.2 \\
4 & - & 151.2 \\
5 & $6.44(\mathrm{dd}, 8.4,3.1)$ & 114.1 \\
6 & $6.58(\mathrm{~d}, 8.4)$ & 116.6 \\
$1^{\prime}$ & $3.28(\mathrm{~d}, 7.3)$ & 29.0 \\
$2^{\prime}$ & $5.57(\mathrm{t}, 7.3)$ & 125.2 \\
$3^{\prime}$ & - & 136.4 \\
$4^{\prime}$ & $3.95(\mathrm{~s})$ & 68.9 \\
$3^{\prime}-$ Me & $1.74(\mathrm{~s})$ & 13.8 \\
\hline \multicolumn{2}{c}{ a) } \\
\multicolumn{2}{c}{ These assignments were established by HMBC, HMQC, DEPT and } \\
\multicolumn{2}{c}{}
\end{tabular}

in a 96-well half-area black microplate (Costar) and incubated for $10 \mathrm{~min}$ at $37^{\circ} \mathrm{C}$. The reaction was started by adding $50 \mu \mathrm{l}$ of fluorescence-quenching peptide substrate solution to the well, and incubated for 2 (MMP-1 and MMP-3) or 3 (MMP-9) hours at $37^{\circ} \mathrm{C}$. Five mu of MOCAc-Pro-Leu-Gly-Leu-A2pr(Dnp)Ala-Arg- $\mathrm{NH}_{2}{ }^{7)}$ (Peptide Institute, Japan) was used as a substrate for MMP-1 and MMP-9, and $5 \mathrm{mM}$ of MOCAc-Arg-Pro-Lys-Pro-Val-Glu-Nva-Trp-ArgLys(Dnp)- $\mathrm{NH}_{2}{ }^{8)}$ (Peptide Institute, Japan) was used as a substrate for MMP-3. After the incubation, the fluorescence intensity $(\mathrm{Ex} / \mathrm{Em}=320 / 405 \mathrm{~nm})$ of each well was measured by a fluorescence microplate reader (Polarstar; BMG LabTechnologies, Germany). $\mathrm{IC}_{50}$ values were calculated from the percentage inhibition by using GraphPad Prism (GraphPad Software, San Diego, CA, U.S.A.).

Compound 1: pale yellow oil; IR (neat) $v_{\max }: 3243$, $1456 \mathrm{~cm}^{-1}$; ${ }^{1} \mathrm{H}$ - and ${ }^{13} \mathrm{C}-\mathrm{NMR}$, Table 1 ; EIMS, $m / z$ $194 \mathrm{[M}^{+}$; HREIMS, $194.0938 \mathrm{[M}^{+}$(calcd. for $\left.\mathrm{C}_{11} \mathrm{H}_{14} \mathrm{O}_{3}, 194.0943\right)$.

Isolation was guided by the MMP-1 inhibition activity of eachfraction. Fresh fruiting bodies of $P$. betulinus were extracted with $85 \%$ EtOH. The extract, after concentrating the solvent, was partitioned between chloroform and water, and then between ethyl acetate and water. Since the EtOAc-soluble fraction showed inhibitory activity, this fraction was separated by repeated chromatography and HPLC to obtain compounds $\mathbf{1}$ and $\mathbf{2}$.

The molecular formula of compound 1 was determined to be $\mathrm{C}_{11} \mathrm{H}_{14} \mathrm{O}_{3}$ by HREIMS. The ${ }^{1} \mathrm{H}-\mathrm{NMR}$ spectrum of 1 showed the presence of a typical 1,2,4trisubstitued phenyl moiety; $\delta 6.53(\mathrm{~d}, J=3.2 \mathrm{~Hz})$, $6.44(\mathrm{dd}, J=8.4,3.1 \mathrm{~Hz}), 6.58(\mathrm{~d}, J=8.4 \mathrm{~Hz})$, a methylene $[\delta 3.28(\mathrm{~d}, J=7.3 \mathrm{~Hz})]$ coupled with a $\mathrm{sp}^{2}-$ methine $[\delta 5.57(\mathrm{t}, J=7.3 \mathrm{~Hz})]$, a hydroxymethyl $[\delta$ $3.95(\mathrm{~s})]$, and a methyl $[\delta 1.74(\mathrm{~s})]$ attached to a $\mathrm{sp}^{2}-$ carbon (Table 1). The complete structure was determined by HMBC and NOESY experiments. The HMBC cross peaks observed were as follows: H3/<smiles>C/C(=C\Cc1cc(O)ccc1O)C(=O)O</smiles>

1<smiles>C=C(CCC(C(=O)O)[C@H]1[C@@H](O)C[C@@]2(C)C3=CCC4C(C)(C)C(=O)CC[C@]4(C)C3=CC[C@]12C)C(C)C</smiles>

Scheme. 1

$\mathrm{C} 1^{\prime}, \mathrm{H} 3 / \mathrm{C} 1, \mathrm{H} 3 / \mathrm{C} 5, \mathrm{H} 5 / \mathrm{C} 1, \mathrm{H} 5 / \mathrm{C} 3, \mathrm{H} 6 / \mathrm{C} 2, \mathrm{H} 6 /$ $\mathrm{C} 4, \mathrm{H}^{\prime} / \mathrm{C} 1, \mathrm{H}^{\prime} / \mathrm{C} 2, \mathrm{H}^{\prime} / \mathrm{C} 3, \mathrm{H}^{\prime} / \mathrm{C}^{\prime}, \mathrm{H}^{\prime} / \mathrm{C} 3^{\prime}$, $\mathrm{H} 2^{\prime} / \mathrm{C}^{\prime}, \mathrm{H} 2^{\prime} / \mathrm{C}^{\prime}-\mathrm{Me}, \mathrm{H} 2^{\prime} / \mathrm{C}^{\prime}, \mathrm{H} 4^{\prime} / \mathrm{C} 3^{\prime}-\mathrm{Me}$, $\mathrm{H} 4^{\prime} / \mathrm{C}^{\prime}{ }^{\prime}, \mathrm{H} 4^{\prime} / \mathrm{C}^{\prime}{ }^{\prime}, \mathrm{H} 3^{\prime}-\mathrm{Me} / \mathrm{C}^{\prime}{ }^{\prime}, \mathrm{H} 3^{\prime}-\mathrm{Me} / \mathrm{C}^{\prime}{ }^{\prime}$, $\mathrm{H} 3^{\prime}-\mathrm{Me} / \mathrm{C}^{\prime}$. The cross peaks between $\mathrm{H} 2^{\prime}$ and $\mathrm{H}-4^{\prime}$, and $\mathrm{H} 1^{\prime}$ and $\mathrm{H} 3^{\prime}-\mathrm{Me}$ in the NOESY spectrum indicated that the stereochemistry of the double bond in 1 was $E$. Thus, the structure of 1 was determined to be (E)-2-(4-hydroxy-3-methyl-2-butenyl)-hydroquinone.

Compound 2 showed an ion peak at $m / z 483$ $[\mathrm{M}+\mathrm{H}]^{+}$by FABMS. The NMR data for $\mathbf{2}$ agree with those of polyporenic acid $\mathrm{C}$ which has been reported as an MMP-1 inhibitor by us $\left(\mathrm{IC}_{50}\right.$ of $126 \mu \mathrm{M}){ }^{9}{ }^{9}$

Compound $\mathbf{1}$ showed inhibitory activity against MMP-1 and its $\mathrm{IC}_{50}$ value was $28 \mu \mathrm{M}$. This compound also inhibited MMP-3 (IC 50 of $23 \mu \mathrm{M}$ ) and MMP-9 $\left(\mathrm{IC}_{50}\right.$ of $\left.37 \mu \mathrm{M}\right)$.

\section{Acknowledgments}

This work was partially supported by grant-in-aid for scientific research on priority areas 'Targeted Pursuit of Challenging Bioactive Molecules' (No. 12045232) from the Ministry of Education, Science, Sports and Culture of Japan, and by grant-aid for scientific research (No. 12490015) from the Japan Society for the Promotion of Science.

\section{References}

1) Alexander, C. W., and Werb, Z., Extracellular matrix degradation. In "Cell Biology of the Extracellular Matrix”, ed. Hay, E. D., Plenum Press, New York, 
pp. 255-302 (1991).

2) Firestein, G. S., Paine, M. M., and Littman, B. H., Gene expression (collagenase, tissue inhibitor of metalloproteinase, complement and HLA-DR) in rheumatoid and osteoarthritic synobium. Arthritis Rheum., 34, 1094-1105 (1991).

3) Walakovits, L. A., Bhardwaj, N., Gallick, G. S., and Lark, M. W., Detection of high levels of stromelysin and collagenase in synovial fluid in patients with rheumatoid arthritis and post-traumatic knee injury. Arthritis Rheum., 35, 35-42 (1992).

4) Pyke, C., Ralfkiaer, E., Huhtala, P., Hurskainen, T., Danoe, K., and Tryggvason, K., Localization of messenger RNA for Mr 72,000 and 92,000 type IV collagenase in human skin cancers by in situ hybridization. Cancer Res., 52, 1336-1341 (1992).

5) Overall, C. M., Weibkin, O. W., and Thonard, J. C., Demonstration of tissue collagenase activity in vivo and its relationship to inflammation severity in human gingiva. J. Periodontal Res., 22, 81-88 (1987).

6) Gijbels, K., Galardy, R. E., and Steinman, L., Reversal of experimental autoimmune encephalomyelitis with a hydroxamate inhibitor of matrix metalloproteinases. J. Clin. Invest., 94, 2177-2182 (1994).

7) Knight, C. G., Willenbrock, F., and Murphy, G., A novel coumarin-labelled peptide for sensitive continuous assay of the matrix metalloproteinases. FEBS Lett., 296, 263-266 (1992).

8) Nagase, H., Fields, C. G., and Fields, G. B., Design and characterization of fluorogenic substrate selectively hydrolyzed by stromelysin 1 (matrix metalloproteinase-3). J. Biol. Chem., 269, 20952-20957 (1994).

9) Kawagishi, H., Li, H., Tanno, O., Inoue, S., Ikeda, S., Ohnishi-Kameyama, M., and Nagata, T., A lanostane-type triterpene from a mushroom Daedalea dickinsii. Phytochemistry, 46, 959-961 (1997). 